\title{
Fashion sebagai Bentuk Ekspresi Diri dalam Komunikasi
}

\author{
Tri Yulia Trisnawati \\ (manyunndud@rocketmail.com) \\ Alumnus Jurusan Ilmu Komunikasi Universitas Semarang
}

\begin{abstract}
This study aims to determine self-expression through the values you want to appear in clothing consumption among adolescent girls as the main consumers of fashion products, to wear certain clothing types, and describes how to overcome obstacles that arise in expressing themselves through fashion. The research methodology used a qualitative descriptive method that focuses on observation and natural setting. Researchers acting as an observer, then create a category of behavior, observed symptoms, and record observations in a book. The research was conducted at the University of Semarang. The subjects in this study is the Student Department of Communication Class of 2008, FTIK, USM, while samples taken by 4 respondents with a purposive sampling technique. Fashion outline as an essential element of fashion and became the core of the interface itself for some adolescent girls, are used to convey messages with specific purposes to be conveyed by the wearer.
\end{abstract}

Keywords: Fesyen, Gaya Busana, Ekspresi Diri, Hambatan, Komunikasi Verbal dan Komunikasi Non-Verbal

\section{Pendahuluan}

Fashion merupakan istilah yang akrab dalam kehidupan sehari-hari. Kita seringkali mengidentikkan fashion dengan busana atau pakaian, padahal sebenarnya yang dikatakan fashion adalah segala sesuatu yang sedang tren dalam masyarakat. Hal ini mencakup busana, selera makan, hiburan, barangbarang konsumsi dan lain-lain. Menurut Alex Thio dalam bukunya, Sociology, "fashion is a great though brief enthusiasm among relatively large number of people for a particular innovation". Jadi sebenarnya fashion bisa mencakup apa saja yang diikuti oleh banyak orang dan menjadi tren. Fashion juga berkaitan dengan unsur novelty atau kebaruan, oleh karena itu fashion cenderung berumur pendek dan dan tidak bersifat kekal. Dan karena yang cenderung bergerak dan selalu berubah setip saat adalah busana, maka fashion sering dikaitkan dengan busana, padahal selama ada sesuatu yang baru tentang suatu artefak yang melibatkan kesenangan banyak orang, itu bisa menjadi fashion (Thio, 1989: 582).

"Fashion terutama busana, merupakan sisi kehidupan masyarakat yang saat ini sedemikian penting sebagai salah satu indikator bagi muncul dan berkembangnya gaya hidup (life style)" (Featherstone, 2001: 197). Fashion merupakan sesuatu yang sering disinonimkan dengan busana, padahal pengertian sesungguhnya fashion bisa mencakup segala sesuatu yang berkaitan dengan adornment, style maupun dress.

Media massa memberikan andil yang tidak sedikit bagi berkembangnya tren busana yang kemudian diikuti oleh sebagian besar perempuan yang ingin tampil trendi dan modis. Dengan adanya media, masyarakat menyamakan cara berpakaian mereka seperti apa 
yang dikenakan idolanya masingmasing. Hal ini terbukti bahwa apa saja sekarang menjadi pusat perhatian di media-media dan dijadikan acuan oleh masyarakat.

Jelas fenomena ini menjadi komoditas di era modern seperti sekarang ini dan ditambah juga peran media yang ikut menyebarkan kapitalis. Saat ini pun banyak kita temui media yang mengkhususkan membahas perkembangan fashion dan lifestyle. Contoh lain yaitu beberapa waktu lalu munculnya boyband bernama $\mathrm{SM}^{*} \mathrm{SH}$ dengan penampilan yang menarik atau berpenampilan dengan gaya ala penyanyi atau boyband korea meramaikan acara-acara media. Menggunakan pakaian yang dibilang gaul atau glamour, mereka bernyanyi sambil berkoreografi. Berbeda dengan yang trend yang lalu, dimana lebih condong meniru gaya anak-anak emo.

(http://nugraheniika.blogspot.com /2011/12/peran-media-terhadapperkembangan_05.html, 1 Februari 2012).

Pakaian merupakan obyek yang oleh sebagian besar orang diangap bisa menyampaikan sesuatu sebagaimana yang dikemukakan oleh Barthes mengenai "the language of fashion", bahwa setiap bentuk fashion pasti mengandung pesan tertentu yang kemudian ingin disampaikan oleh pemakainya. Hal ini dianggap benar dan diakui oleh sebagian besar orang. Fashion merupakan obyek yang dianggap bisa menyampaikan makna dan maksud-maksud tertentu dari pemakainya. Oleh karena itu dengan pakaian yang dikenakan diharapkan orang bisa menilai tanda-tanda yang ditampilkan dengan pakaian yang dikenakannya. Misalnya saja gaya busana anak punk, yang selalu memakai baju dan celana warna hitam-hitam, ingin menunjukkan pesan yakni kebebasan.

Fashion sebagai ekspresi diri dan komunikasi dari pemakainya memberikan implikasi bagi penggunaan fashion dalam kaitannya dengan bagaimana orang mengkomunikasikan nilai, status, kepribadian, identitas, dan perasaan kepada orang lain. Ciri dan identitas pribadi menjadi sesuatu yang sangat penting untuk ditunjukkan ketika kita hidup dalam masyarakat, dimana individualitas menjadi tolak ukur penilaian dalam sebuah hubungan maupun interaksi. Karena fashion bisa mengekspresikan sesuatu yang tidak terucap secara verbal inilah, maka fashion juga seringkali digunakan untuk menunjukkan identitas personal dari individu yang bersangkutan. Hanya dengan mengenakan jenis pakaian tertentu maka, orang lain akan bisa menilai kepribadian dan citra dirinya. Sementara itu, diantara para perempuan, pada tataran usia remajalah mereka cenderung lebih terpengaruh oleh perkembangan fashion. Mereka yang cenderung masih belum stabil, selalu mencoba hal-hal baru, ingin selalu menonjolkan diri terutama di mata lawan jenisnya. Fashion memang identik dengan perempuan, hal ini sudah menjadi common knowledge yang hampir semua orang mengakuinya. Diantara perempuan-perempuan, mulai dari kecil, remaja, hingga dewasa dan tua, maka pada tataran remajalah demam fashion begitu berpengaruh dalam kehidupan mereka.

Berdasarkan latar belakang diatas, maka perumusan masalah yang akan dijawab adalah sebagai berikut:

1. Bagaimana cara mahasiswi Jurusan Ilmu Komunikasi angkatan 2008, Fakultas Teknologi Informasi dan Komunikasi, Universitas Semarang dalam menggunakan fashion sebagai bentuk ekspresi diri? 
2. Bagaimana cara mahasiswi Jurusan Ilmu Komunikasi angkatan 2008, Fakultas Teknologi Informasi dan Komunikasi, Universitas Semarang menghadapi hambatan-hambatan dalam mengekspresikan diri melalui fashion?

\section{Tinjauan Pustaka}

\section{Teori Sistem Semiotik}

Menurut Roland Barthes, mitos adalah "culture's way of thinking" tentang sesuatu dan cara mengkonseptualisasi atau memahami budaya tersebut. "Mitos merupakan sebuah cerita (narasi) dimana ia menjelaskan budaya atau memahami beberapa aspek dari realitas atau $n a-$ ture" (Fiske, 1990:88). Mitos bekerja untuk menaturalkan history dan merupakan tahap kedua dari proses signifikasi. Dalam Element of Semiology, Barthes dengan meminjam skema Saussure, menambahkan satu tahapan lagi dalam signification process. Ia membagi proses menandai menjadi denotation (primary signification) dan connotation (secondary signification). Pada level kedua inilah mitos diproduksi dan dikonsumsi (Storey, 1993:78).

Dalam sistem semiotik, menurut Barthes (1967), tidak hanya kata-kata dan image tetapi objek itu sendiri bisa berfungsi sebagai signifier dalam produksi makna. Busana misalnya bukan sekedar cover of the body tetapi juga mempunyai tanda-tanda karena mereka membentuk makna dan membawa sebuah pesan. Misalnya pakaian malam menandakan elegan, dasi panjang menandakan formalitas, jeans sebagai casual dress. Tanda-tanda ini memungkinkan busana membawa makna dan fungsi selayaknya bahasa, "the language of fashion". Namun demikian, tidak semua orang membaca fashion dengan cara yang sama, ada perbedaan gender, usia, kelas, dan ras. Akan tetapi semua yang berbagi codecode fashion yang sama akan menginterprestasikan tanda-tanda itu relatif sama pula (Hall, 1997:38).

"Sistem semiologi ini erat kaitannya dengan implikasi dari sistem representasi. Representasi adalah produksi makna melalui bahasa" (Hall, 1997:24). Bahasa merupakan syarat mutlak bagi terjadinya proses representasi ini. Dalam proses representasi ada dua tahap yang sangat menentukan yaitu mental representation. Disini terdapat sistem yang mana obyek, manusia dan peristiwa dikorelasikan dengan sebuah konsep yang ada dalam pikiran kita. Sedangkan tahap kedua adalah bagasa, yang mencakup semua proses dari pembentukan makna (Hall, 1997:18). Maka disinilah arti penting bahasa dalam proses representasi.

Produk-produk

fashion

merupakan obyek yang senantiasa memiliki nilai-nilai dan citra-citra tertentu yang selalu dilekatkan dan tidak bisa terpisah dengan fashion itu sendiri. Oleh sebab itu orang beranggapan bisa memperoleh nilai-nilai tanda tertentu dengan mengkonsumsi produk-produk tersebut. Hal ini merupakan implikasi dari kerja mitos yang menjadikan sesuatu itu sebagai sebuah naturalisasi dan telah demikian adanya.

Fashion merupakan obyek yang sarat dengan citra dan gaya hidup. Orang memakai selembar baju bukan semata-semata karena nilai guna (use value). Akan tetapi lebih karena adanya nilai atau citra tertentu yang ingin dicapai dengan memakai busana tersebut. Misalnya: cantik, modis, trendi, anggun, elegan dan femininin. Dengan demikian use value bukan menjadi tujuan utama orang memilih sebuah baju untuk dipakainya, melainkan lebih disebabkan sign 
valuenya. Dalam masyarakat consumer seperti saat ini, fashion menjadi ciri, identitas dan kepribadian dari pemakainya. Konsumerisme dan gaya hidup menjadikan prestise citra, perbedaan sebagai suatu kebutuhan (need), kesemuan dan artifisial yang ada dibaliknya dianggap sebagai kebenaran (Piliang, 1998:35).

\section{Budaya Populer}

Budaya populer (biasa disingkat sebagai budaya pop dalam bahasa Inggris popular culture atau disingkat pop culture) adalah gaya, style, ide, perspektif, dan sikap yang benar-benar berbeda dengan budaya arus utama 'mainstream' (yang preferensinya dipertimbangkan di antara konsensus informal). Banyak dipengaruhi oleh media massa (setidaknya sejak awal abad ke-20) dan dihidupkan terusmenerus oleh berbagai budaya bahasa setempat, kumpulan ide tersebut menembus dalam keseharian masyarakat. Awal mula penggunaan kata "popular" dalam bahasa Inggris adalah pada abad kelima belas dalam hukum dan politik, yang berarti rendah "rendah", "dasar", "vulgar", dan "masyarakat kebanyakan"; sejak akhir abad kedelapan belas, popular berarti "luas" dan mendapatkan arti konotasi yang positif (William, 1985). Kata "Culture" di kalangan pengguna bahasa Inggris, sejak tahun 1950-an digunakan untuk mengacu pada berbagai kelompok masyarakat, dengan penekanan pada perbedaan budaya. (http://budaya-

pop.blogspot.com/2010/09/budayapopuler.html, 1 Februari 2012).

\section{Fashion}

Tak dapat dipungkiri, dalam realita yang sarat dengan image dan citra saat ini, penampilan menjadi hal yang sangat penting dalam kehidupan sosial.
Orang berhubungan dengan orang lain seringkali dengan terlebih dulu melihat penampilan fisiknya, dan pakaian merupakan obyek fisik yang paling tampak ketika kita berinteraksi dengan orang lain. Oleh karena itu fashion menjadi simbol-simbol nonverbal yang ingin disampaikan oleh pemakainya, fashion and clothing are form of nonverbal communication in that they do not use spoken or written words (Barnard, 1996:26).

Bila kita berbicara mengenai fashion, maka kita pasti akan langsung tertuju pada makhluk yang bernama perempuan. Tak salah lagi, dunia fashion memang dunia yang identik dengan perempuan. Sebagian besar trend fashion yang muncul dan berkembang memang diperuntukan bagi konsumsi laki-laki. Menurut Wilson bahwa, "fashion is, righty or wrongly, primarity associated with women" (Barnard, 1996:22) adalah benar adanya. Secara fisik perempuan memang berbeda dengan laki-laki, hal ini memang tak dapat dipungkiri. Oleh karena itu busana untuk perempuan sering dibedakan dengan laki-laki. Busana untuk perempuan cenderung memiliki jenis dan model yang bermacammacam. Sedangkan busana untuk lakilaki biasanya lebih bersifat konvensional, modelnyapun relatif sama satu sama lain dan tidak banyak detailnya.

Diantara para perempuan, pada tataran usia remajalah mereka cenderung lebih terpengaruh oleh perkembangan fashion. Mereka yang cenderung masih belum stabil, selalu mencoba hal-hal baru, ingin selalu menonjolkan diri terutama di mata lawan jenisnya. Oleh karena itu penampilan fisik diperhatikan dalam masa ini. Sebenarnya terdapat banyak batasan mengenai remaja, dimana antara satu dan lainnya seringkali jauh 
berbeda. Hal ini dikarenakan pembatasan usia dimana seseorang bisa dikatakan remaja atau tidak sangat dipengaruhi oleh faktor sosiodemografis seperti budaya maupun nilai-nilai dari masyarakat dimana remaja itu tinggal.

Posisi dan keberadaan remaja sebagai salah satu konsumen utama produk fashion memang relevan. Hal ini berkaitan dengan kondisi psikologis mereka yang cenderung masih belum stabil, selalu mencoba hal-hal yang baru, ingin selalu menonjolkan diri terutama di mata lawan jenisnya. Pakaian bisa membuat orang merasa berbeda dalam konteks yang berbeda. Terutama untuk perempuan dalam usia remaja, pakaian yang mereka kenakan dalam suatu kesempatan akan mempengaruhi cara mereka bicara, berperilaku dan penampilan mereka.

\section{Komunikasi Verbal dan Nonverbal}

Komunikasi terbagi menjadi dua yakni komunikasi verbal dan nonverbal. Simbol atau pesan verbal adalah semua jenis simbol yang menggunakan satu kata atau lebih. Bahasa dapat juga dianggap sebagai sistem kode verbal (Deddy Mulyana, 2005). Bahasa dapat didefinisikan sebagai seperangkat simbol, dengan aturan untuk mengkombinasikan simbol-simbol tersebut, yang digunakan dan dipahami suatu komunitas. Sedangkan, komunikasi nonverbal adalah komunikasi yang menggunakan pesanpesan nonverbal. Istilah nonverbal biasanya digunakan untuk melukiskan semua peristiwa komunikasi di luar kata-kata terucap dan tertulis. Secara teoritis komunikasi nonverbal dan komunikasi verbal dapat dipisahkan. Namun dalam kenyataannya, kedua jenis komunikasi ini saling jalin menjalin, saling melengkapi dalam komunikasi yang kita lakukan sehari- hari. (komunikasi-verbal-dan-nonverbal.html, 25 Mei 2011).

Komunikasi nonverbal merupakan bagian yang tidak dapat dipisahkan dari komunikasi verbal. Pesan-pesan nonverbal seringkali mengikuti proses komunikasi verbal. Menurut Leathers komunikasi nonverbal diklasifikasikan menjadi 3 bagian, yaitu : pesan nonverbal visual (meliputi kinetik atau gerak tubuh, proksemik atau penggunaan ruangan personal dan sosial, artifaktual seperti pakaian, kosmetik), pesan nonverbal auditif (meliputi paraliguistik), dan pesan nonverbal nonvisual nonauditif atau tidak berupa kata-kata, tidak terlihat dan tidak terdengar (meliputi sentuhan dan penciuman) (Rakhmat, 2000:289).

Fashion merupakan pesan artifaktual yang ditampakkan melalui penampilan tubuh. Pakaian akan tampak begitu orang saling berhadapan. Bahkan ketika keduanya belum saling menyapa sekalipun. Menurut Kefgan dan Touchie, "pakaian menyampaikan pesan, pakaianterlihat sebelum suara terdengar...pakaian selalu berhubungan dengan perilaku tertentu" (Rakhmat 2000:292). Hal ini seringkali tampak dalam kehidupan sehari-hari, dimana kita seringkali menilai orang dari penampilan fisiknya, terutama yang diperlihatkan dari bagaimana cara dia berbusana.

\section{Metodologi Penelitian}

1. Jenis Penelitian

Penelitian yang dilakukan adalah penelitian deskriptif kualitatif, dalam penelitian kualitatif ada beberapa asumsi yang mendasarinya, seperti yang dikemukakan oleh Merriam (Creswell, 1994: 145):
- Peneliti kualitatif lebih memberikan makna pada proses daripada hasil. 
- Peneliti kualitatif tertarik pada makna yaitu bagaimana orang berusaha memahami kehidupan, pengalaman dan struktur lingkungan mereka.

- Peneliti kualitatif merupakan instrumen utama dalam pengumpulan analisis data.

- Peneliti kualitatif terkait dengan fieldwork. Artinya peneliti terlibat langsung secara fisik dengan orang, latar (setting), tempat atau institusi untuk mengamati dan mencatat perilaku dalam latar alamiahnya.

- Bersifat deskriptif, artinya peneliti tertarik pada proses makna dan pengalaman yang diperoleh melalui kata-kata dan gambargambar.

- Peneliti kualitatif bersifat induktif, dimana peneliti membangun abstraksi, konsep, input dan teori.

Dari konsep-konsep dasar dalam penelitian kualitatif sebagaimana disebutkan diatas, maka secara praktis penelitian ini berusaha mengkaji peristiwa yang ada dan terjadi dalam realita dan dialami oleh subyek penelitian.

Adapun penelitiannya adalah deskriptif kualitatif, dimana metode deskriptif mencari teori bukan menguji teori (Hypothesisgenerating, bukan Hypothesis testing, dan heuristic, bukan verifikasi). Ciri lain metode deskriptif kualitatif ialah menitikberatkan pada observasi dan suasana alamiah (natural setting). Peneliti terjun langsung ke lapangan, bertindak sebagai pengamat, lalu membuat kategori perilaku, mengamati gejala, dan mencatatnya dalam buku observasi (instrumennya adalah pedoman observasi). Ia tidak berusaha untuk memanipulasi variable (Dr.Elvinaro, 2010: 60).
1. Lokasi Penelitian

Penelitian ini dilakukan di Universitas Semarang, karena peneliti melibatkan mahasiswi Ilmu Komunikasi USM.

2. Subyek Penelitian

Peneliti memberi spesifikasi bahwa subyek yang diambil adalah mahasiswi Jurusan Ilmu Komunikasi angkatan 2008, Fakultas Teknologi Informasi dan Komunikasi, Universitas Semarang. Dengan alasan, peneliti mengenal subyek penelitian dengan cukup baik, sehingga tercipta frame of reference (konsep berpikir) yang serupa, sehingga akan mudah dalam membentuk kerangka pemahaman yang sama. Namun demikian, peneliti tetap berupaya untuk menjaga objektivitas penelitian. Selain itu, peneliti juga melakukan konfirmasi hasil penelitian dengan peneliti lain yang melakukan penelitian serupa.

3. Sumber Data

Data primer dari penelitian ini diperoleh dengan cara melakukan wawancara mendalam (in-depth interview) terhadap responden. Penentuan responden dengan mengaplikasikan pengambilan sample secara purposive sampling dengan karakteristik sebagai berikut:

a. Perempuan remaja usia 1725 tahun, secara spesifik yakni mahasiswi Jurusan Ilmu Komunikasi Angkatan 2008, Fakultas Teknologi Informasi dan Komunikasi, Universitas Semarang.

b. Mahasiswi yang fashionable (selalu mengikuti model 
pakaian yang sedang trend), dengan ciri-ciri sebagai berikut:

- Subyek yang sering mengakses situs fashion (seperti Blog, online shop yang ada dalam daftar pertemanan di facebook, maupun situs-situs fashion lainnya), atau membaca majalah lifestyle (seperti Kosmopolitan, Kawanku, Gadis, B'girl, Cosmogirl, Hai, Femina, Kartini).

- Subyek juga bisa dipilih berdasarkan acara televisi yang mereka tonton (seperti Jelang Siang di Trans TV, Warna di Trans7, Show Buzz di Metro TV). Mengapa acara tesebut dipilih karena menurut peneliti walaupun hanya selintas namun acara tersebut seringkali membahas perkembangan fashion.

- Subyek penelitian paling tidak mengakses situs, ataupun menonton acara fashion minimal dalam enam bulan terakhir.

- Penelitian ini dilakukan dengan menggunakan interview guide sebagai dasar dan pedoman wawancara. Menurut Koentjaraningrat, wawancara dilakukan untuk mendapatkan keterangan, data atau informasi yang berkaitan dengan permasalahan yang akan diteliti

(Koentjaraningrat, 1991: 130), dengan menggunakan alat bantu berupa tape-recorder untuk mencatat dan merekam hasil wawancara.

- Data skunder dalam penelitian ini diperoleh melalui kajian pustaka yang relevan dengan permasalahan penelitian seperti; buku-buku, majalah, surat kabar dan data dari internet.

4. Teknik Pengumpulan Data

Wawancara:

Menurut Burhan Bungin (2005: 67)., wawancara adalah sebuah dialog yang dilakukan oleh pewawancara untuk memperoleh informasi dari terwawancara. Wawancara ini digunakan untuk mengetahui keaslian pendapat dari subyek penelitian tentang nilai-nilai yang ingin ditampilkan dalam pemakaian jenis busana tertentu.

Telaah Kepustakaan:

Pengumpulan data maupun informasi yang berasal dari sumber tertulis yang berkaitan dengan masalah yang diteliti, diantaranya: buku, surat kabar, majalah, maupun informasi dari situs-situs internet.

5. Teknik Analisis Data

Menurut Whitney analisis data adalah upaya untuk mencari dan menata secara sistematis catatan wawancara, telaah kepustakaan dan lainnya untuk meningkatkan pemahaman peneliti tentang kasus yang diteliti dan menyajikannya sebagai temuan bagi orang lain. Data tersebut diolah dan dianalisa kembali 
maksudnya agar menjadi ringkas, yang meliputi proses mulai dari menuliskan kembali hasil wawancara atau rekaman yang dilakukan dilapangan yang kemudian dilanjutkan dengan kegiatan mengedit, mengklasifikasikan, mereduksi serta menyajikannya. Sementara itu untuk meningkatkan pemahaman tersebut, analisis perlu dilanjutkan dengan upaya mencari makna (meaning). Penelitian ini dilakukan menggunakan analisis deskriptif kualitatif.

\section{Hasil dan Pembahasan}

\section{Fashion dalam Ekspresi Diri} Remaja

Diantara masa hidup perempuan, pada tataran usia remajalah mereka begitu memperhatikan perkembangan fashion. Hal ini dikarenakan pada masa ini biasanya mereka cenderung menempatkan penampilan fisik diatas segalanya atau "appearance is key", maka dari itu segala sesuatu yang dapat memperindah dan mempercantik penampilannya akan selalu mereka adopsi. Bagi banyak remaja pakaian merupakan sesuatu yang sangat penting seperti makanan dan air. Para remaja ini mengekspresikan diri mereka melalui apa yang mereka pakai dan bagaimana penampilan mereka. Hal ini dikarenakan remaja merupakan masa ketika mereka berusaha menciptakan identitas mereka sendiri dan sebagian besar diekspresikan melalui fashion.

Dalam paradigma remaja, apa yang mereka pakai akan menetukan keberhasilan mereka dalam hubungan pertemanan maupun hubungan cinta mereka. Dengan pakaian yang mereka kenakan, kemudian mereka melekatkan nilai, kesan, pesan maupun maksud tertentu yang memang biasanya telah melekat pada pakaian yang mereka kenakan. Sejalan dengan konsep yang dikemukakan oleh Willis, "young people learn about their inner selves partly by developing their outer image through clothes. They use style in the symbolic work to express and develop their understanding of themselves as unique person, to signifying who they are and they think tey are" (Willis, 1990: 89).

\section{Fashion sebagai Bentuk Ekspresi Diri dalam Komunikasi (Mendiskripsikan Nilai-Nilai Pemakaian Busana) \\ Fashion merupakan ungkapan} yang seringkali kita dengar dan ucapkan untuk menunjukkan busana yang senantiasa berubah dan berganti dalam setiap musim peragaan busana. Padahal arti sesunguhnya dari fashion cukup berbeda dengan pemahaman orang saat ini. Menurut Alex Thio, "fashion is a great though brief enthusiasm among relatively large number of people for particular innovation". Dari sini kita bisa tahu bahwa fashion bisa mencakup segala sesuatu yang diikuti oleh banyak orang dan kemudian menjadi trend. Dalam paradigma fashion juga dikenal unsur novelty atau kebaruan, karena yang cenderung bergerak dan selalu berubah setiap waktu adalah busana, maka fashion sering diidentikkan dengan busana (Thio, 1989: 582).

Setelah peneliti melakukan riset tentang pengertian fashion, dari beberapa informan yang ada, menurut peneliti informan Wida-lah yang sesuai dengan apa yang dikemukakan Alex Thio. Wida mengatakan, "Fashion itu menurut saya lebih ke perkembangan model. Model apa saja...ya model pakaian, rambut, make-up, segala macemlah tentang perempuan mencakup semuanya perkembangan model". 
Fashion dalam realitas sosial yang ada saat ini, bukan saja dipergunakan karena nilai gunanya. Akan tetapi fashion lebih dipandang karena nilai-nilai tanda yang terkandung di dalamnya. Orang memakai fashion untuk mengungkapkan maksud dan tujuan tertentu serta untuk menyampaikan pesan secara nonverbal. Oleh karena itu fashion dianggap dianggap bisa menunjukkan identitas dan ciri individu maupun kepribadiannya. Seperti yang diungkapkan Barthes (1967), dalam teori sistem semiotik tidak hanya katakata dan image tetapi objek itu sendiri bisa berfungsi sebagai signifier dalam produksi makna. Begitu juga dengan busana, bukan sekedar cover of the body tetapi juga mempunyai tanda-tanda karena mereka membentuk makna dan membawa sebuah pesan.

Hal ini seperti yang diungkapkan Dias, "Menurut saya dari busana bisa menunjukkan kepribadian seseorang, misalnya dengan berbusana girly maka orang tersebut memiliki pribadi yang lembut dan manja layakna sifat wanita pada umumnya. Tidak hanya kepribadian, busana juga bisa menunjukan status sosial seseorang, yaitu dari merk busana yang dikenakan dari designer ternama atau cuman copyan busana branded"

Berbeda dengan yang dikatakan Wida, "Biasanya sih bisa. Misalnya yang simpel-simpel saja, kata orang kebanyakan cewek yang saat di lingkungan kampus atau lingkungan umum memakai rok mini atau pakaian yang agak ketat gitu, pasti orang akan menilai sebagai cewek nakal. Padahal hal itu belum tentu benar begitu, siapa tahu memang dia gemar memakai busana yang semacam itu. Terus juga misalkan anak-anak yang ikut komunitas punk atau emo itu juga menampilkan cara dia berbusana. Jadi itukan konsep dan kepribadiannya mereka saja".

Dari dua informan tadi dapat kita ambil kesimpulan, bahwa dari setiap busana yang kita kenakan terkandung pesan-pesan yang secara nonverbal disampaikan kepada orang lain yang melihat, dan kemudian muncullah bermacam-macam tanda hasil dari busana yang kita pakai. Dimana setiap orang yang menerima tanda tersebut, memiliki penilaian tersendiri akan tanda itu.

\begin{tabular}{llr}
\multicolumn{1}{c}{ Fashion selalu mengadopsi } \\
konsep modern & dalam \\
perkembangannya, dimana & fashion \\
selalu berubah sesuai & dengan \\
berjalannya & waktu. & Padahal \\
sesungguhnya perkembangan & fashion
\end{tabular}
itu cenderung hanya bergerak memutar. Seperti halnya sesuatu yang dulu pernah in pasti suatu saat juga akan kembali menjadi tren. Maka dari itu banyak muncul istilah "back to 60 's, back to 80's". Seperti yang diungkapkan Dias, "Seperti yang saya katakan sebelumnya kalau fashion berkembang dengan pesat, dan hal ini menurut saya sangat positif karena kita tidak akan tertingal dengan negara lain. Sebetulnya tren fashion selalu berputar, seperti tren sebelum korean style yaitu tren fashion jadul atau masa 60an. Dimana gaya busana orang tua kita jaman remaja dulu menjadi tren pada masa sekarang".

Untuk mensiasati percepatan fashion, ada beberapa cara yang biasa dilakukan oleh para informan untuk mensiasatinya, yaitu:

1. Menyimpan busana-busana tersebut supaya bisa dipakai kembali saat tren lagi. Seperti yang diungkapkan Dias: "Saya menyimpan busana-busana yang saya miliki dengan rapi karena apabila tren fashion tersebut kembali booming maka saya sudah memilkinya tinggal dipadupadankan 
dengan apik sehingga bisa mengikuti tren lagi".

2. Melakukan mix'n'match busana yang lama dengan busana yang baru. Solusi ini diungkapkan oleh Tika: "Di mix n' match. Ya bagaimana kita pinter-pinternya mix n' match, dimodifikasi lagilah. Mungkin seperti punyanya baju-baju lama dikasih aja rompi. Atau sekarangkan lagi trennya legging-legging, yang pokoknya pinter-pinternya dimodif aja, tapi jangan lupa yang penting itu nyaman".

3. Kembali ke individu masing-masing, apakah kita termasuk orang yang mengunggulkan unsur novelty (kebaruan) atau tetap dengan pendirian kita dengan mengandalkan kenyamanan. Seperti yang diungkapkan Wida: "Menurutku lebih balik ke orangnya masingmasing. Kalau memang dia suka mengikuti tren fashion pasti disaat fashion berubah lagi pasti akan mengikuti. Tapi kalau aku misalnya aku nyaman dengan cara berbusana aku yang saat ini seperti ini, bukan berarti kalau misalkan aku pakai besok-besok ke fashion yang baru nanti terkesan jadulkan juga enggak. Jadi ini tergantung gimana nyamannya kita aja ya. Belum tentu kalau kita ngikutin fashion tapi ternyata waktu kita nerapin ke diri kita ga' nyaman ya sama saja, buat apa? Yang penting kenyamanannya aja".

Seiring dengan berjalannya waktu, mau tak mau kita pasti mengikuti perkembangan fashion ada. Dari kesimpulan tadi, muncul banyak hambatan-hambatan saat kita mengikuti fashion. Mulai dari segi finansial, pengaruh lingkungan sekitar, postur tubuh yang menentukan cocok enggaknya kita memakai busana tersebut, dan sebagainya. Hal serupa juga diungkapkan oleh Dias: "Hambatan yang saya alami yaitu financial dan paling uptodate diantara teman-teman. Untuk hambatan dalam hal financial itu yang paling sering saya alami karena fashion selalu berubah setiap saat dimana saya harus menyediakan dana untuk membelinya".

Begitu juga Tika: "Hambatannya kembali lagi ke ekonomi ya. Pakaian sekarang memang lebih murah-murah ya tapi tergantung kualitas juga, terus sama pemilihan karakternya juga. Kita pasti memiliki satu bentuk karakter tapi disesuaikan sama kondisi dan keadaan serta acara yang juga berubah karakternya". Berbeda dengan Wida yang mengenakan jilbab, dia mengungkapkan: "Iya, Hambatannya semacam lebih ke masalah biaya sama postur tubuh, jadi tidak semua-semua cocok. Kalau masalah berpakaian aku malas pakai baju rangkap-rangkap gitu. Lagian juga kalau make baju lengen tanggung itu ga' apa-apa, tapi tanggunya jangan sampai ke siku...paling ga' ya dibawah siku $3 / 4$ gitu”.

Karena banyaknya hambatanhambatan tersebut, kita dapat mengatasinya dengan:

- Hambatan Financial dapat kita atasi dengan menyisihkan uang saku, seperti yang diungkapkan Dias: "Saya menyiasatinya dengan cara menyisihkan uang harian yang diberikan orang tua, dengan begitu saya tidak harus merepotkan orang tua kalau ingin membeli busana yang lagi tren".

- Menjadi seseorang yang ter-update, Dias mengatakan: "Saya mengatasinya dengan membaca majalah-majalah fashion dan sering mengunjungi mall”.

- Menjadi diri sendiri. Tika mengungkapkan: “...Meski fashion itu berkembang...kita perlu 
menjadi diri sendiri. Meski fashion itu berkembang seperti apapun kalau kita yakin merasa cocok, nyaman, kita percaya diri ya gak apa-apa".

- Pemilihan busana yang sesuai dengan karakter individu. Seperti yang dikatakan Wida: "Kalau misalkan, hambatan masalah fisik...ya harus di pas'in, jangan kalau tidak cocok maksa mau pakai, nanti orang melihatnya aneh. Lagipula kalau misalkan ga' bagus, atau aku pake kayaknya orang melihatnya kok aneh ya? Yaudah jangan dilanjutin lagi. Jadi juga harus rajin-rajin Tanya juga”.

\section{Kesimpulan}

Dari uraian diatas, beberapa hal yang dapat disimpulkan antara lain:

1. Fashion saat ini telah mengalami perubahan nilai, yang awalnya dianalogikan pada aspek fungsional (use value), yakni sebagai pelindung tubuh dari cuaca, kini lebih memiliki makna tanda (sign value) dimana busana dapat bermakna saat dikorelasikan dengan nilai-nilai sosial yang ada.

2. Fashion terutama busana dalam kehidupan yang erat dengan image dan citra ini dipercaya untuk menjadi salah satu bentuk tanda komunikasi yang bisa menyampaikan makna-makna yang disampaikan secara nonverbal.

3. Perempuan yang paling banyak memfungsikan fashion sebagai nilai tanda dibanding laki-laki. Hal itu dikarenakan oleh sistem nilai masyarakat yang menuntut perempuan untuk sadar akan kualitas fisiknya yang secara keberadaannya berbeda dengan laki-laki.

4. Menjadi cantik dan menarik merupakan fungsi perempuan. Oleh karena itu pemakaian busana, nilai kecantikannya biasanya menjadi hal yang mendasari mereka dalam pemilihan busana tertentu.

5. Seorang perempuan dicirikan dengan pribadi yang feminin, anggun, serta elegan. Oleh sebab itu dengan busana yang dikenakannya, perempuan berusaha untuk selalu menunjukkan identitas jati diri mereka. Sehingga busana menjadi petunjuk yang mengarahkan mereka pada nilainilai tersebut.

6. Nilai aktualisasi diri merupakan salah satu bagian yang penting untuk ditunjukkan oleh perempuan, dalam hal ini perempuan usia remaja. Karena dengan itu seorang perempuan akan memperoleh rasa percaya diri yang amat berharga ketika dia menunjukkan eksistensi dirinya di masyarakat. Sebagai bagian dari nilai aktualisasi diri perempuan, busana merupakan obyek untuk mendapatkan nilai percaya diri tersebut. Berusaha tampil dengan busana-busana yang fashionable untuk membuktikan bahwa ia ada dan eksis.

7. Fashion yang up to date dianalogikan dengan selalu mengikuti perkembangan jaman yang dalam fashion atau busana diimplikasikan dengan tren fashion terbaru menjadi bagian penting yang patut untuk ditunjukkan dan menjadi dasar bagi pemakaian busana dikalangan perempuan, terutama usia remaja.

8. Seiring berjalannya waktu, mau tak mau kita juga pasti mengikuti perkembangan fashion yang ada. Dari kesimpulan tersebut, muncul banyak hambatan-hambatan. Mulai dari segi finansial, pengaruh lingkungan sekitar, postur tubuh yang menentukan cocok atau 
enggaknya kita mengenakan jenis busana tersebut.

9. Dalam pemakaian busana dikalangan remaja, menyangkut beberapa hal yang menjadi indikasi dari gaya mereka berbusana, yang dapat dilihat dari: pemilihan jenis busana yang kemudian akan menunjukkan citra dan nilai apa yang mereka inginkan, keberadaan model sebagai panutan, saluran yang mempengaruhi perubahan nilai fashion, serta gaya konsumsi mereka.

10. Perempuan remaja biasanya memilah-milah busana mereka dalam dua kategori, yaitu busana sehari-hari dan busana untuk eventevent khusus. Busana sehari-hari biasanya cenderung casual (santai) dan trendy. Sedangkan untuk busana event-event khusus cenderung dipilih untuk menimbulkan kesan formil, feminin, anggun, glamor, dan sopan namun tetap modis.

\section{Daftar Pustaka}

Barnard, Malcolm. 1996. Fashion as Communication. London: Routledge.

Creswell, John W. 1994. Research Design, Qualitative and Quantitative Approach. California: Sage Publications.
De Vito, Joseph A. 1995. The Interpersonal Communication book: Seventh Edition. New York: Harpercallins Collage Publisers.

Elvinaro Ardianto. 2010. Metodologi Penelitian Untuk Public Relation Kuantitatif dan Kualitatif. Bandung: Simbiosa Rekatama Media.

Featherstone, Mike. 2001. Posmodernisme dan Budaya Konsumen. Pustaka Pelajar.

Fromm, Erich. 2002. Cinta Seksualitas Matriarkhi Gender. Yogyakarta: Jalasutra.

Hall, Suart. 1997. Representation (Cultural Representation and Signifying Prsctices). London: Sage Publications.

Noeng Muhadjir. 1996. Metode Peneletian Kualitatif. Edisi Ketiga. Yoyakarta: Rake Sarash.

Yasraf Amir Piliang. 1998. Dunia yang Dilipat. Yogyakarta: Mizan.

Thio, Alex. 1987. Sociology (An Introduction). New York: Westview.

Adi P. $\quad$ http://budayapop.blogspot.com/2010/09/buday a populer.html; Budaya Pop; diunduh pada 1 Februari 2012.

Nugrahenika.http://nugraheniika.blogsp ot.com/2011/12/peran-mediaterhadap-perkembangan_05.html; Peran Media Terhadap Perkembangan Fashion; 1 Februari 2012. 